\title{
Determination of acrylamide-induced chick embryo brain glutathione S-transferases expression through enzyme activity and western blot
}

\author{
Sreenivasulu Dasari*, Sailaja Gonuguntla, Balaji Meriga, Thyagaraju Kedam \\ Department of Biochemistry, Sri Venkateswara University, Tirupati, Andhra Pradesh, India
}

\begin{tabular}{|c|c|}
\hline ARTICLE INFO & ABSTRACT \\
\hline $\begin{array}{l}\text { Article history: } \\
\text { Received on: September } 02,2017 \\
\text { Accepted on: October 24, } 2017 \\
\text { Available online: January } 17,2018\end{array}$ & $\begin{array}{l}\text { Glutathione S-transferases (GSTs) are major detoxification enzymes which belong to Phase II defense enzymes; } \\
\text { they can able to metabolize a variety of toxic chemical agents such as carcinogens, genotoxins, neurotoxins, and } \\
\text { pesticides. Usually, GST will express when the living beings are encountered toxic chemical compounds. Acrylamide } \\
\text { (ACR) is synthesized industrially and widely used in various industries. Usually, ACR formation occurs when food }\end{array}$ \\
\hline $\begin{array}{l}\text { Key words: } \\
\text { Chick embryo brain glutathione } \\
\text { S-transferases, } \\
\text { Acrylamide, } \\
\text { Glutathione S-transferases } \\
\text { expression, } \\
\text { Western blot }\end{array}$ & $\begin{array}{l}\text { products prepared at high temperature. So that ACR is an environmental and food contaminant and it is well-proven } \\
\text { neurotoxin. Due to highly mobile nature, birds that include poultry birds are main victims to xenobiotics (e.g., ACR) } \\
\text { through food, water, and agricultural chemical formulas. In this study, ACR administered chick embryo brain GST } \\
\text { activity level was assayed using 1-chloro-2,4-dinitrobenzene, and expression was assessed by western blot studies. } \\
\text { The results show that the GST expression levels were increased in response to ACR by } 24 \text { and } 48 \text { h intervals. } \\
\text { However, in } 48 \text { h interval, GST expression levels decreased slightly. Western blot studies also show similar pattern } \\
\text { of GST expression. Immune blot studies showed similar GST band pattern as purification studies showed (our } \\
\text { published work). In this study, enzyme activity and western blot analysis proved that the chick embryo brain GST } \\
\text { was expressed more to detoxify ACR. }\end{array}$ \\
\hline
\end{tabular}

\section{INTRODUCTION}

Glutathione S-transferases (GSTs) [E.C.2.5.1.18] are Phase II defense enzymes, and they certainly involved in cellular detoxification and excretion of various xenobiotic molecules $[1,2]$; this is the versatile defense enzyme that requires GSH for antioxidant function. Usually, toxic agents such as carcinogens and environmental pollutants including oxidative stress products are detoxified by GSTs, which conjugate an electrophilic center with reduced GSH [3]. GSTs can detoxify a wide range of hazardous substances by transferase activity and GST associated peroxidase activity [4]. Cytosolic GSTs are dimeric proteins, those have 199-244 amino acids in length and 23-30 kDa molecular mass [5]. Based on amino acid sequence similarities, mammalian cytosolic GSTs (human, rat and mouse) were classified as alpha $(\alpha)$, $\mathrm{mu}(\mu)$, pi $(\pi)$, theta $(\tau)$, sigma $(\sigma)$, zeta $(\zeta)$, and omega $(0)[2,6]$. The avian GSTs have a complex isoenzyme system, but researchers put little attention on them. A xenobiotic which shown noxious effects

\section{*Corresponding Author}

Dr. Sreenivasulu Dasari,

Department of Biochemistry,

Sri Venkateswara University,

Tirupati - 517 502, Andhra Pradesh, India.

Phone: +91-8978935568.

Email: dasarisreenivaasulu@gmail.com by direct interaction with specific sites on cellular macromolecules (e.g., enzymes), and this interaction is dictated by the chemical nature of the toxicant $[7,8]$. There are no prominent studies about antioxidant enzymes and biomarkers of oxidative stress that related to various bird species $[9,10]$. Birds have peculiar molecular mechanisms such as (1) low rates of mitochondrial oxygen radical production and (2) high blood glucose levels compared to other vertebrates, and birds can effectively defend free radicals and oxidative stress by this peculiar feature [11].

Acrylamide (ACR) is an electrophile; it causes cytotoxicity through interaction with nucleophile residues of biological macromolecules such as enzymes and DNA by covalent bonds [12,13]. ACR is formed in carbohydrate-rich food products, those prepared at high temperature in addition to environmental accumulation. Orally administered ACR can rapidly absorbed into the blood circulation, and hence, distributed to vital organs and reacts with nerve cells, enzymes, hemoglobin, and cellular DNA [14]. ACR can suppress metabolism and axonal transport in neurons which leads to a deficiency of nutritional factors [15]. ACR shows its toxic effect on both central nervous system and peripheral nervous system [16]. Both oxidative stress and apoptosis play a key role in ACR-induced toxicity [17-19]. ACR-induced lipid peroxidation is the reason for decrease of antioxidant ability in nervous tissue and sciatic nerve [20]. According to the previous literature, ACR has carcinogenic, 
reproductive, and neurotoxic properties [21,22], induces apoptosis in cerebral cortex [19], and efficiently binds to the brain [23]. In both laboratory animals and humans, ACR neurotoxicity is characterized by ataxia and distal skeletal muscle weakness [24]. That the brain, spinal cord and sciatic nerve affect to the ACR-induced oxidative stress in the nervous system including sensory and motor dysfunction in rats [20]. The present study is aimed to evaluate the expression of chick embryo brain GSTs by ACR administration through enzyme activity and western blot studies.

\section{MATERIALS AND METHODS}

\subsection{Chemicals}

ACR (99.9\%), GSH (reduced), N,N-methylene-bis-ACR, $\beta$-mercaptoethanol, 1-chloro-2,4-dinitrobenzene (CDNB), 5-bromo4-chloro-3-indolyl phosphate (BCIP), nitroblue tetrazolium (NBT), Ponceau-S stain, and Freund's incomplete and complete adjuvants were purchased from Bio-Rad laboratories, Richmond, USA, and Genei, Bengaluru, India. Goat anti-rabbit IgG antibodies (Bio-Rad laboratories, Richmond, USA) and nitrocellulose (NC) membrane (Amersham, UK) were gifted by my friend Reddy Peera, National Brain Research Center, Gurgaon, Haryana, India. Ammonium persulfate, ethylenediaminetetraacetic acid (EDTA), glycine, hydroxymethyl aminomethane (Tris base), phenylmethanesulfonyl fluoride (PMSF), sodium azide, sodium dodecyl sulfate (SDS), sodium chloride $(\mathrm{NaCl})$, potassium chloride, skim milk powder, and all required chemicals were purchased from the local chemical companies with high quality.

\subsection{Maintenance of Eggs and Route of Chemical Administration}

Fertilized Babcock strain chicken eggs weighing about $50 \mathrm{~g}$ were incubated at $37^{\circ} \mathrm{C}, 60 \%$ humidity, and were rotated for every $3 \mathrm{~h}$. On the $12^{\text {th }}$ and $15^{\text {th }}$ day of incubation eggs were injected under sterile conditions with ACR in ppm $(1 \mathrm{mg} / \mathrm{L})$ in distilled water as vehicle. Control eggs were injected with vehicle only. A hole was made in the shell at the blunt end of the egg, and a microsyringe was inserted through the air sac, onto the inner shell membrane, where 2-6 ppm ACR was deposited. Usually, the inner shell membrane has direct contact with the chorioallantoic membrane. Hence, this route of administration gives a faster uptake of the substances than yolk injections. During this process, the survival embryos were tested using Candler light. The dead eggs were discarded and survived eggs were selected for the experiments.

\subsection{Tissue Collection and Sample Preparation}

Brain tissue was collected from normal and treated $18^{\text {th }}$-day embryos by pressing small head with forceps and washed with cold $50 \mathrm{mM}$ Tris $\mathrm{HCl}$ buffer ( $\mathrm{pH} 8.0$ ), containing $1 \mathrm{mM}$ EDTA to remove excess blood and body fluids, and instantly collected tissue was preserved at $-20^{\circ} \mathrm{C}$ for further experimentation. At the time of experimentation, the brain tissues were slightly thawed and $20 \%$ of brain tissue homogenate was prepared in $50 \mathrm{mM}$ Tris- $\mathrm{HCl}$ buffer ( $\mathrm{pH}$ 8.0) containing $0.25 \mathrm{M}$ sucrose and $1 \mathrm{mM}$ PMSF using a potter Elvijhem homogenizer. Homogenization was done by keeping the potter Elvijhem homogenizer in an ice jacket, and care was taken to minimize the froth formation. The homogenate was passed through two layers of cheesecloth to remove floating lipid materials, and the resulting supernatant was centrifuged at $10,000 \mathrm{rpm}$ on high-speed refrigerated centrifuge by 2 times for $45 \mathrm{~min}$ at $4{ }^{\circ} \mathrm{C}$. The collected supernatant was known as cytosolic fraction, and it was used as the enzyme source for purification and activity assays.

\subsection{Assay of GST Activity}

Conjugation of reduced GSH to CDNB was stimulated by the addition of cellular protein as described by Habig et al. [25]. Briefly, $100 \mathrm{mg}$ of cellular fractions was added to cuvettes containing $30 \mathrm{mM}$ CDNB 100 $\mu 1$ and $30 \mathrm{mM} \mathrm{GSH} 100 \mu 1$ and with phosphate buffer (pH 6.5) adjust for a final volume of $1.0 \mathrm{ml}$. Change in absorbance $(340 \mathrm{~nm}$ ) was measured over a span of 3 min to calculate the rate of conjugation of CDNB and expressed as $\mu$ mole CDNB-GSH conjugate formed $/ \mathrm{min} / \mathrm{mg}$ protein.

\subsection{Estimation of Protein}

Protein concentration was determined in both control and treated sample by the method of Lowry et al. [26].

\subsection{Antisera Production}

That the affinity-purified GST protein was used for immunization of rabbits (New Zealand white male, 3 months old) to produce antibodies after SDS PAGE analysis as described by Laemmli [27]. Rabbit was obtained from Department of Physiology, Sri Venkateswara Veterinary University, Tirupati. Blood was collected from rabbit, and serum was stored as control for further experimental analysis. That the rabbit hair was removed at 4-6 sites, and then, $200 \mathrm{mg}$ of affinitypurified GST protein per ml was emulsified with an equal volume of Freund's complete adjuvant and that emulsified mixture was injected subcutaneously to the rabbit at 4-6 sites. The booster doses were given with an interval of a week for about 4-5 times. Titer of antibodies was tested before the fifth dose of immunization. The last dose was given with an incomplete adjuvant. 1 week after the last injection, the rabbit was bled and the serum was centrifuged at $6,000 \mathrm{rpm}$ by Remi refrigerated centrifuge for $30 \mathrm{~min}$ at $4{ }^{\circ} \mathrm{C}$ and that the collected supernatant was considered as antisera of chick embryos brain GSTs.

\subsection{Electroblotting}

According to Towbin et al. [28], electroblotting was carried out using Mini Blot Module (Vertical Gel System-EC 120, USA) and NC membrane. SDS-PAGE gel was placed for $30 \mathrm{~min}$ in Towbin buffer, i.e., $25 \mathrm{mM}$ Tris HCL (pH 8.8), $192 \mathrm{mM}$ glycine, and 20\% methanol. The NC membrane was washed several times with distilled water and then with Towbin transfer buffer until it was equilibrated and precaution was taken that the membrane should not become dry. The blotting stack was assembled on the top of stainless steel grid cathode located in the trough of the frame stand of the mini blot module, to which transfer buffer was added (about $2.5 \mathrm{Lit}$ ). The red lead was connected to the anode and the black lead to the cathode, and the proteins transfer was allowed to move anions to the direction of anode. The transfer process was performed at $4{ }^{\circ} \mathrm{C}$ for overnight using a constant voltage of $35 \mathrm{~V}$. The NC membrane was removed and placed in the Ponceau-S stain to check the transferred protein bands.

\subsection{Immunostaining of NC Membrane}

Immunostaining was carried out according to the instruction manual provided with the goat anti-rabbit IgG secondary antibodies, and all of the incubations were performed in a minimum of $5 \mathrm{ml}$ of solutions in each step with continuous shaking at room temperature.

The electroblotted NC membrane was incubated in the blocking solution ( $5 \%$ non-fat dry milk powder) in transfer buffer saline (TBS) for $30 \mathrm{~min}$. After that, the NC membrane was incubated with chick embryo brain anti-GST primary antibodies (1:2000 dilutions) in the blocking solution for $30 \mathrm{~min}$. After hybridization with primary antibodies, NC membrane was then washed 5 times with TBS 
(5 min each) and incubated with the secondary antibody (goat antirabbit IgG-ALP conjugate) with the 1:5000 dilution in TBS for $5 \mathrm{~h}$. After that, the membrane was washed 3 times ( 5 min each) with TBS, and then, the ALP conjugate color developing solution (BCIP/ NBT) was added. The specific protein bands started to appear after 1030 min. Finally, the membranes were carefully dried, and the images were obtained using a scanner connected to the computer.

\subsection{Statistical Analysis}

All the data related to the present study and documented results were calculated from three different experiments, and they presented as the mean \pm standard deviation (SD). Student $t$-test was used in this study to identify AC-treated brain samples difference from the mean for respective controls. The difference between experimental groups at the level $0 P<0.05$ was considered as statistically significant.

\section{RESULTS}

\subsection{GST Expression Studies}

\subsubsection{GST activity assay}

As shown in Table 1 and Figure 1, in $24 \mathrm{~h}$ interval, expressed GST activity was significantly increased to 4.0 -fold and 8.5 -fold with 2 ppm ACR and 4 ppm ACR, respectively, and decreased to 0 . 6-fold with $6 \mathrm{ppm}$ of ACR than 8.5 -fold by $4 \mathrm{ppm}$ of ACR when compared to control, i.e., 4.0-fold.

As shown in Table 2 and Figure 2, in $48 \mathrm{~h}$ interval, expressed GST activity was significantly increased to 4.7-fold and 8.2-fold with 2 ppm ACR and 4 ppm ACR, respectively, and decreased to 0.8 -fold with 6 ppm of ACR than 8.2-fold by 4 ppm of ACR when compared to control, i.e., 5.3-fold.

\subsubsection{Western blot analysis}

As shown in Figure 3, in $24 \mathrm{~h}$ interval, GST expression levels were significantly increased in response to $2 \mathrm{ppm}$ ACR and $4 \mathrm{ppm}$ ACR,

Table 1: Activity profile of chick embryo brain GSTs in response to ACR by $24 \mathrm{~h}$ interval.

\begin{tabular}{llc} 
Acrylamide & Sample: Chick embryo brain & Substrate: CDNB \\
& Control & $0.04 \pm 0.02$ \\
$2 \mathrm{ppm}$ & $0.08 \pm 0.04^{\mathrm{a}}$ \\
$4 \mathrm{ppm}$ & $0.125 \pm 0.09^{\mathrm{a}}$ \\
$6 \mathrm{ppm}$ & $0.119 \pm 0.05^{\mathrm{a}}$ \\
\hline
\end{tabular}

The values represented in Table 1 are average of three separate experiments of three samples. Mean \pm SD. Student test ( ${ }^{a} P<0.05$, regarded as significant activity of GST). ACR was administered by doubling the dose $2 \mathrm{ppm}$ per day by $24 \mathrm{~h}$ interval. One unit GST activity is expressed as $\mu$ mole GSH-CDNB conjugate formed $/ \mathrm{min} / \mathrm{mg}$ protein, GST: Glutathione S-transferases, ACR: Acrylamide

Table 2: Activity profile of chick embryo brain GSTs in response to ACR by $48 \mathrm{~h}$ interval.

\begin{tabular}{llc} 
Acrylamide & Sample: Chick embryo brain & Substrate: CDNB \\
& Control & $0.053 \pm 0.02$ \\
$2 \mathrm{ppm}$ & $0.1 \pm 0.06^{\mathrm{a}}$ \\
$4 \mathrm{ppm}$ & $0.135 \pm 0.09^{\mathrm{a}}$ \\
$6 \mathrm{ppm}$ & $0.127 \pm 0.05^{\mathrm{a}}$ \\
\hline
\end{tabular}

The values represented in Table 2 are average of three separate experiments of three samples. Mean \pm SD. Student test ( ${ }^{a} P<0.05$, regarded as significant activity of GST). ACR was administered by doubling the dose $2 \mathrm{ppm}$ per day by $48 \mathrm{~h}$ interval. One unit GST activity is expressed as $\mu$ mole GSH-CDNB conjugate formed $/ \mathrm{min} / \mathrm{mg}$ protein. GSTs: Glutathione S-transferases, ACR: Acrylamide but GST expression levels were slightly decreased in response to $6 \mathrm{ppm}$ ACR. Similarly, in $48 \mathrm{~h}$ interval, GST expression levels were significantly increased in response to $2 \mathrm{ppm}$ ACR and 4 ppm ACR, but GST expression levels were slightly decreased in response to $6 \mathrm{ppm}$. Initially, GST expression was activated when ACR entered into cell, but excess infiltration of ACR leads to deactivation of GST expression.

\section{DISCUSSION}

Either intentionally or unintentionally, environment is continuously loading by toxic chemical compounds (xenobiotic) and metals, which released mainly through industries, in the $20^{\text {th }}$ century, thousands of organic pollutants were produced and released them into the environment [29]. Usually, oxidative damage is associated with lot of environmental factors such as weather, availability of food, competition between intra- and inter-specific species, and risk of predation; those factors are vary in different stages of life such as reproduction, hibernation, moulting, and migration; these factors put the animals long period under pressure [11]. In addition to the normal metabolism, detoxification of toxic compounds can also generate various reactive oxygen species (ROS); they promote the oxidative stress in species which are living in contaminated environment [30].

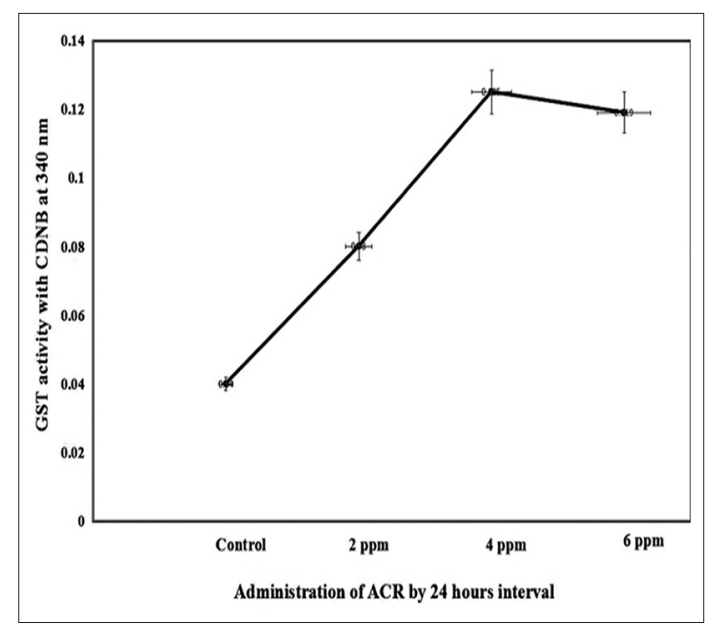

Figure 1: Activity of chick embryo brain glutathione S-transferases by the administration of acrylamide by $24 \mathrm{~h}$ interval.

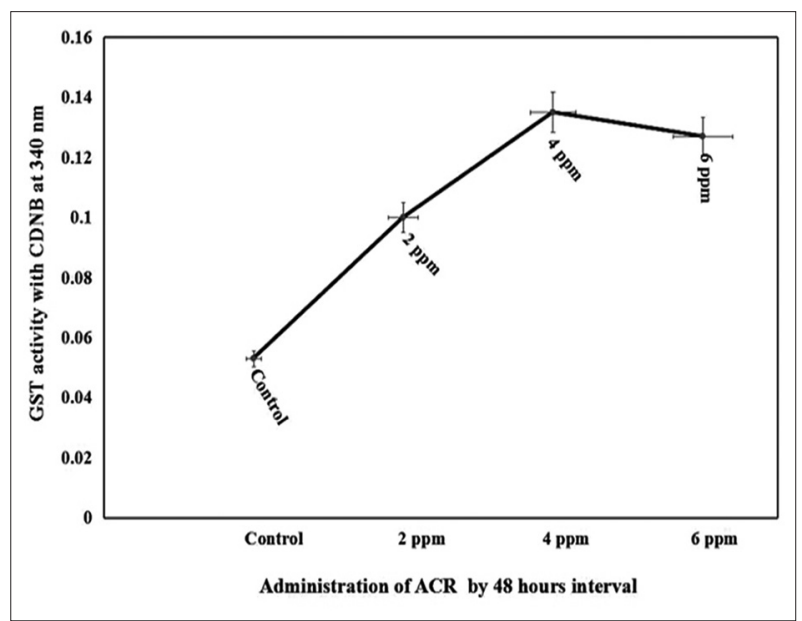

Figure 2: Activity of chick embryo brain glutathione S-transferases by the administration of acrylamide by $48 \mathrm{~h}$ interval. 


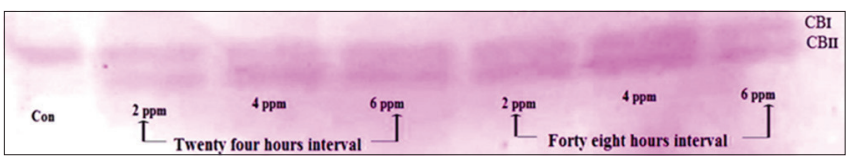

Figure 3: Western blot of chick embryo brain glutathione S-transferases expressed by the administration of acrylamide.

Different strategies have developed by organisms to face the ROS causing physiological imbalance by antioxidant enzymatic system and non-enzymatic antioxidant molecules [11,31]. Biological cells handle the ROS using GSH antioxidant system includes GSTs; it protects cells from oxidative stress $[32,33]$. In bird species, detoxification efficiency is sometimes associated with the type of diet [34], and sometimes, it is connected to the metabolic rate [35]. ACR is a neurotoxin, and it can absorbed into the by several ways such as respiration, digestive system, and skin including muscle. In addition to that, ACR can rapidly spread throughout the body. GSTs are key enzymes to defend cell against cytotoxic and carcinogenic agents [5]. The remarkable change in expression of drug metabolizing enzymes which may significantly show influence on metabolism and biological effects of drugs, industrial, and environmental contaminants [36].

In the present study, expressed GST activity by the administration of ACR was evaluated in each dose and interval, using universal substrate of GST, i.e., CDNB. As shown in Table 1 and 2 and Figures 1 and 2, with the substrate CDNB, GST activities were significantly increased to 4.0 -fold and 8.5 -fold by $24 \mathrm{~h}$ interval, 4.7 -fold and 8.2 -fold by $48 \mathrm{~h}$ interval, in response to $2 \mathrm{ppm} \mathrm{ACR}$ and $4 \mathrm{ppm}$ ACR, respectively, and decreased to 0.6 -fold by $24 \mathrm{~h}$ interval, 0.8 -fold by $48 \mathrm{~h}$ interval, in response to $6 \mathrm{ppm}$ ACR than $4 \mathrm{ppm}$ (8.5-fold and 9.5-fold) of ACR in both intervals, when compared to control, i.e., 4.0-fold and 5.3-fold, respectively, in both intervals.

As shown in Figure 3, chick embryo brain GST expression levels were significantly increased from 2 ppm ACR to 4 ppm ACR in both intervals, respectively, and slightly decreased by $6 \mathrm{ppm}$ ACR, in both intervals.

As shown in Tables 1 and 2 and Figures 1 and 2, it was observed that the GST activity was increased to 4.0 -fold and 8.5 -fold by $24 \mathrm{~h}$ interval, and 4.7 -fold and 8.2 -fold by $48 \mathrm{~h}$ interval, in response to $2 \mathrm{ppm}$ ACR and $4 \mathrm{ppm}$ ACR, respectively, when compared to 4.0-fold of control in both intervals. Here, elevation of GST activity in response to ACR was observed in this study, and this may be due to increased process of detoxification. As in Figure 3, immunoblot with the primary antibody that specific to chick embryo brain GSTs showed band pattern similar to purified GST band pattern ( $\mathrm{CB}_{\mathrm{I}}$ and $\mathrm{CB}_{\mathrm{II}}$, our published work), and it was observed that the increased levels of GST expression in response to $2 \mathrm{ppm}$ ACR and $4 \mathrm{ppm}$ ACR. Here, elevation of GST expression in response to ACR was observed by immunoblot analysis; it may be due to increased process of detoxification. As shown in Tables 1 and 2, and Figure 1 and 2, it was observed that the GST activity decreased to 0.6 -fold and 0.8 -fold in response to 6 ppm ACR than 8.5-fold and 9.5fold by $4 \mathrm{ppm}$ ACR, respectively, in both intervals, when compared to control of both intervals, i.e., 4.0-fold and 5.3-fold, respectively. Here, a decrease of GST activity in response to ACR was observed, and this may be due to deactivation of GST by excess ACR. Similarly as shown in Figure 3, it was observed that the slightly decreased levels in GST expression in response to $6 \mathrm{ppm}$ ACR in both intervals. Here, decrease of GST expression was observed by immunoblot analysis, and this may be due to suppression of GST expression by excess ACR.
A potent inducer may involve in transcriptional upregulation of Phase II drug metabolism enzyme genes [37]. That the biotransformation enzymes which can protect organisms from potentially toxic chemicals and ROS. Usually, ROS can damage macromolecules under oxidative stress conditions, while antioxidant enzymes of the body are expressed more [38]. It was reported that the increased activities of GST may protect rat from xenobiotic, and they alter drug metabolism that is, especially, GST substrates [39]. ACR is potent neurotoxin [15,40] and can induce neurotoxicity in both prenatal and perinatal rodents [41,42]. Purification studies and substrate specific reaction studies show that $\mathrm{CB}_{\mathrm{I}}$ and $\mathrm{CB}_{\mathrm{II}}$ GSTs of chick embryo brain have similarity with alpha $(\alpha)$ and mu $(\mu)$ class GSTs [43]. Chick embryo brain GST protein biomarkers can protect the developing brain from environmental toxic chemical agents [44]. Therefore, the present study was agreed with the study of 37-39, [15], 40-44.

\section{CONCLUSION}

Chick embryo brain cytosolic GST activity was elevated in response to $2 \mathrm{ppm}$ and $4 \mathrm{ppm}$ ACR, in $24 \mathrm{~h}$ and $48 \mathrm{~h}$ intervals, but that GST activity was decreased in response to $6 \mathrm{ppm}$ of ACR, in both intervals with the substrate CDNB. Western blot revealed, expression of cytosolic GSTs was elevated from $2 \mathrm{ppm}$ to $4 \mathrm{ppm}$ of ACR by $24 \mathrm{~h}$ and $48 \mathrm{~h}$ intervals, but decreased by $6 \mathrm{ppm}$ of ACR, in both intervals. Increased of GST activity was due to an increase of GST expression, and this certain condition may occur when detoxification process increases. Decrease of GST activity was due to suppression of GST expression, and this may be due to excess accumulation of ACR. Key conclusion, through western blot studies and purification studies that includes biochemical characterization, under normal physiological condition as well as under neurotoxic chemicals, same GSTs were expressed in chick embryo, i.e., $\mathrm{CB}_{\mathrm{I}}$ and $\mathrm{CB}_{\mathrm{II}}$, and these GSTs expression may elevate to detoxify neurotoxins.

\section{ACKNOWLEDGMENTS}

I am grateful to the University Grants Commission (UGC), New Delhi, India who given generous financial assistance as JRF and SRF (ROC. No. 20601/UGC-1/2/RGNF/2007).

\section{REFERENCES}

1. Eaton DL, Bammler TK. Concise review of the glutathione S-transferases and their significance to toxicology. Toxicol Sci 1999;49:156-64.

2. Frova C. Glutathione transferases in the genomics era: New insights and perspectives. Biomol Eng 2006;23:149-69.

3. Konishi T, Kato K, Araki T, Shiraki K, Takagi M, Tamaru Y. Molecular cloning and characterization of alpha-class glutathione S-transferase genes from the hepatopancreas of red sea bream, Pagrus major. Comp Biochem Physiol C Toxicol Pharmacol 2005;140:309-20.

4. Dasari S, Ganjayi MS, Oruganti L, Balaji H, Meriga B. Glutathione S-transferases detoxify endogenous and exogenous toxic agentsminireview. J Dairy Vet Anim Res 2017;5:1-3.

5. Hayes JD, Pulford DJ. The glutathione S-transferase supergene family: Regulation of GST and the contribution of the lsoenzymes to cancer chemoprotection and drug resistance Part II. Crit Rev Biochem Mol Biol 1995;30:521-600.

6. Hayes JD, Flanagan JU, Jowsey IR. Glutathione transferases. Annu Rev Pharmacol Toxicol 2005;45:51-88.

7. Liebler DC. Protein damage by reactive electrophiles: Targets and consequences. Chem Res Toxicol 2007;21:117-28.

8. Lopachin RM, Decaprio AP. Protein adduct formation as a molecular 
mechanism in neurotoxicity. Toxicol Sci 2005;86:214-25.

9. Norte AC, Ramos JA, Sousa JP, Sheldon BC. Variation of adult great tit Parus major body condition and blood parameters in relation to sex, age, year and season. J Ornithol 2009;150:651-60.

10. Hegseth MN, Camus L, Helgason LB, Bocchetti R, Gabrielsen GW, Regoli F. Hepatic antioxidant responses related to levels of PCBs and metals in chicks of three Arctic seabird species. Comp Biochem Physiol C Toxicol Pharmacol 2011;154:28-35.

11. Pamplona R, Costantini D. Molecular and structural antioxidant defenses against oxidative stress in animals. Am J Physiol Regul Integr Comp Physiol 2011;301:R843-63.

12. Lopachin RM, Gavin T, Decaprio A, Barber DS. Application of the hard and soft, acids and bases (HSAB) theory to toxicant - Target interactions. Chem Res Toxicol 2012;25:239-51.

13. Schwöbel JA, Koleva YK, Enoch SJ, Bajot F, Hewitt M, Madden JC, et al. Measurement and estimation of electrophilic reactivity for predictive toxicology. Chem Rev 2011;111:2562-96.

14. Rayburn JR, Friedman M. L-cysteine, N-acetyl-L-cysteine, and glutathione protect Xenopus laevis embryos against acrylamideinduced malformations and mortality in the frog embryo teratogenesis assay. J Agric Food Chem 2010;58:11172-8.

15. LoPachin RM. The changing view of acrylamide neurotoxicity. Neurotoxicology 2004;25:617-30.

16. Sickles DW, Stone JD, Friedman MA. Fast axonal transport: A site of acrylamide neurotoxicity? Neurotoxicology 2002;23:223-51.

17. Sumizawa T, Igisu H. Suppression of acrylamide toxicity by carboxyfullerene in human neuroblastoma cells in vitro. Arch Toxicol 2009;83:817-24.

18. Alturfan AA, Tozan-Beceren A, Sehirli AO, Demiralp E, Sener G, Omurtag GZ. Resveratrol ameliorates oxidative DNA damage and protects against acrylamide-induced oxidative stress in rats. Mol Biol Rep 2012;39:4589-96.

19. Lakshmi D, Gopinath K, Jayanthy G, Anjum S, Prakash D, Sudhandiran G. Ameliorating effect of fish oil on acrylamide induced oxidative stress and neuronal apoptosis in cerebral cortex. Neurochem Res 2012;37:1859-67.

20. Zhu YJ, Zeng T, Zhu YB, Yu SF, Wang QS, Zhang LP, et al. Effects of acrylamide on the nervous tissue antioxidant system and sciatic nerve electrophysiology in the rat. Neurochem Res 2008;33:2310-7.

21. Pourentezari M, Talebi A, Abbasi A, Khalili MA, Mangoli E, Anvari M. Effects of acrylamide on sperm parameters, chromatin quality, and the level of blood testosterone in mice. Iran J Reprod Med 2014;12:335-42.

22. Sen E, Tunali Y, Erkan M. Testicular development of male mice offspring's exposed to acrylamide and alcohol during the gestation and lactation period. Hum Exp Toxicol 2015;34:401-14.

23. Sumner SC, Selvaraj L, Nauhaus SK, Fennell TR. Urinary metabolites from F344 rats and B6C3F1 mice coad ministered acrylamide and acrylonitrile for 1 or 5 days. Chem Res Toxicol 1997;10:1152-60.

24. Yu S, Son F, Yu J, Zhao X, Yu L, Li G, et al. Acrylamide alters cytoskeletal protein level in rat sciatic nerves. Neurochem Res 2006;31:1197-204.

25. Habig WH, Pabst MJ, Jakoby WB. Glutathione S-transferases. The first enzymatic step in mercapturic acid formation. J Biol Chem 1974;249:7130-9.

26. Lowry OH, Rosebrough NJ, Farr AL, Randall RJ. Protein measurement with the folin phenol reagent. J Biol Chem 1951;193:265-75.

27. Laemmli UK. Cleavage of structural proteins during the assembly of the head of bacteriophage T4. Nature 1970;227:680-5.
28. Towbin H, Staehelin T, Gordon J. Electrophoretic transfer of proteins from polyacrylamide gels to nitrocellulose sheets: Procedure and some applications 1979. Biotechnology 1992;24:145-9.

29. Helm PA, Milne J, Hiriart-Baer V, Crozier P, Kolic T, Lega R, et al. Lake-wide distribution and depositional history of current-and pastuse persistent organic pollutants in Lake Simcoe, Ontario, Canada. J Great Lakes Res 2011;37:132-41.

30. Valko M, Morris H, Cronin MT. Metals, toxicity and oxidative stress. Curr Med Chem 2005;12:1161-208.

31. Hu B, Deng L, Wen C, Yang X, Pei P, Xie Y, et al. Cloning, identification and functional characterization of a pi-class glutathione-S-transferase from the freshwater mussel Cristaria plicata. Fish Shellfish Immunol 2012;32:51-60.

32. Limón-Pacheco JH, Gonsebatt ME. The glutathione system and its regulation by neurohormone melatonin in the central nervous system. Cent Nerv Syst Agents Med Chem 2010;10:287-97.

33. Ballatori N, Krance SM, Notenboom S, Shi S, Tieu K, Hammond CL. Glutathione dysregulation and the etiology and progression of human diseases. Biol Chem 2009;390:191-214.

34. Fossi MC, Massi A, Lari L, Marsili L, Focardi S, Leonzio C, et al. Interspecies differences in mixed function oxidase activity in birds: Relationship between feeding habits, detoxication activities and organ chlorine accumulation. Environ Pollut 1995;90:15-24.

35. Ronis MJ, Walker CH. The microsomal monooxygenase of birds. Revi Biochem Toxicol (USA)1989;10:301-84.

36. Testa B, Krämer SD. The Biochemistry of Drug Metabolism: Volume 2: Conjugations, Consequences of Metabolism, Influencing Factors. $1^{\text {st }}$ ed., Vol. 2. (Zurich and Weinheim) New Jersey (USA): Wiley-VCH; 2010.

37. Ow YY, Stupans I. Gallic acid and gallic acid derivatives: Effects on drug metabolizing enzymes. Curr Drug Metab 2003;4:241-8.

38. Rizvi SI, Maurya PK. Alterations in antioxidant enzymes during aging in humans. Mol Biotechnol 2007;37:58-61.

39. Vyskocilová E, Szotáková B, Skálová L, Bártíková H, Hlavácová J, Boušová I. Age-related changes in hepatic activity and expression of detoxification enzymes in male rats. Biomed Res Int 2013;2013:408573.

40. LoPachin RM, Balaban CD, Ross JF. Acrylamide axonopathy revisited. Toxicol Appl Pharmacol 2003;188:135-53.

41. Takahashi M, Shibutani M, Nakahigashi J, Sakaguchi N, Inoue K, Morikawa $\mathrm{T}$, et al. Limited lactational transfer of acrylamide to rat offspring on maternal oral administration during the gestation and lactation periods. Arch Toxicol 2009;83:785-93.

42. Garey J, Paule MG. Effects of chronic oral acrylamide exposure on incremental repeated acquisition (learning) task performance in Fischer 344 rats. Neurotoxicol Teratol 2010;32:220-5.

43. Dasari S, Gonuguntla S, Ganjayi M, Meriga B, Kedam T. Biochemical characterization of glutathione S-transferases purified from chick embryo brain. J Anim Poult Sci 2016;5:42-51.

44. Dasari S, Ganjayi MS, Meriga B, Kedam T. Developmental neurotoxicity of acrylamide: Defensive role of chick embryo glutathione s-trans-ferases. Adv Anim Vet Sci 2017;5:299-306.

How to cite this article:

Dasari S, Gonuguntla s, Meriga B, Kedam T. Determination of acrylamideinduced chick embryo brain glutathione S-transferases expression through enzyme activity and western blot. J App Biol Biotech. 2018;6(1):43-47. DOI: $10.7324 / J A B B .2018 .60108$ 